УДК 025.35:004.78]:004.057.6

Коваленко Світлана Георгївна

науковий співробітник відділу наукового опрацювання документів і організації каталогів Державна науково-педагогічна бібліотека України ім. В. О. Сухомлинського, м. Київ, Україна skovalenko@yandex.ua

\title{
КОНВЕРТУВАННЯ БІБЛІОГРАФІЧНИХ ЗАПИСІВ 3 АІБС «MARC-SQL» У САБ «ІРБІС»: ПРОБЛЕМИ І ЇХ РОЗВ’ЯЗАННЯ
}

\begin{abstract}
Анотація. Основною метою діяльності бібліотечних закладів $є$ формування єдиного інформаційного простору на основі об'єднання і взаємовикористання ресурсів й інтеграція в регіональний, національний, європейський i світовий простір. Утім на шляху до кооперування виникають перепони, серед яких - проблеми міжсистемної взаємодії, що перешкоджають вільному обміну бібліографічними даними і змушують бібліотеки під час створення різного роду корпорацій об'єднуватися за принципом однакових автоматизованих бібліотечно-інформаційних систем. Стаття присвячена конвертуванню бібліографічних записів 3 програми АІБC «MARC-SQL» у програму САБ «IPБIC», проблемам, що виникли в ході цієї роботи і шляхам їх розв’язання.
\end{abstract}

Ключові слова: конвертування; конвертори; кооперування; автоматична інформаційнобібліотечна система; АІБС; система автоматизації бібліотек; САБ; «MARC-SQL»; «IPБIC».

\section{1. ВСТУП}

Постановка проблеми. Нині суттєво скорочується фінансування бібліотечної галузі, що спричинює втрату кваліфікованих кадрів і, головне, порушує відтворення матеріально-технічної бази книгозбірень. У зв'язку з цим ускладнюється доступ до інформаційних ресурсів, погіршується якість обслуговування читачів, i, як результат, понижується роль бібліотек у системі інформаційних комунікацій.

Пошуки оптимальних шляхів удосконалення діяльності сучасних бібліотек для задоволення інформаційних потреб суспільства актуалізують процеси бібліотечної взаємодії. Нині рівень бібліотечного сервісу вийшов за рамки окремої установи. Потреба економії фінансових і технічних засобів, обміну інформацією підштовхує бібліотеки до координації і кооперування діяльності, як до єдиного дійового засобу їхнього існування, який допоможе збагатити інформаційні ресурси через взаємообмін даними, а також оптимізувати управління бібліотечними ресурсами [4]. Підтвердженням правильності таких рішень $є$ спроби бібліотечних працівників об'єднувати зусилля на регіональному і місцевому рівнях.

Отже, основною метою бібліотечних закладів $\epsilon$ формування єдиного інформаційного простору на основі об'єднання і взаємовикористання ресурсів й інтеграція в регіональний, національний, європейський і світовий простори [1]. Утім на шляху до кооперування виникають перепони, серед яких - проблеми міжсистемної взаємодії, що перешкоджають вільному обміну бібліографічними даними і змушують бібліотеки під час створення різного роду корпорацій об'єднуватися за принципом однакових автоматизованих бібліотечно-інформаційних систем (АБІС) [2]. Наразі вдається охопити не всіх потенційних учасників об'єднання з іншими АБІС.

3 проблемою міжсистемної взаємодії Державна науково-педагогічна бібліотека України імені В. О. Сухомлинського (далі - Бібліотека) стикнулась, виконуючи роботу 3 конвертування бібліографічних записів (БЗ) з електронного каталогу, створеного в програмному забезпеченні Автоматизована інформаційно-бібліотечна система «MARC- 
SQL» (далі - АIБC «MARC-SQL») у програму Система автоматизації бібліотек «ІРБІС» (далі - САБ «ІРБІС»).

Перш ніж приступити до роботи з конвертування БЗ, було проведено ретельні дослідження з цієї теми. На жаль, публікацій ані в українських, ані в доступних зарубіжних джерелах знайдено не було. На нечисленних форумах, присвячених проблемам конвертування записів, корисних відомостей також не виявилося.

Метою статті $\epsilon$ висвітлення проблем, які виникали під час конвертування бібліографічних записів з АІБС «MARC-SQL» у програму САБ «IPБIC».

Електронний каталог (ЕК) Бібліотека започаткувала в 2003 p. на базі АІБС «MARC-SQL». Упродовж трирічного періоду роботи в цьому програмному забезпеченні напрацьовано таке:

- створено кілька робочих і функціональних бібліографічних баз даних (БД), зокрема КНИГИ, ДИСЕРТАЦІЇ, АВТОРЕФЕРАТИ ДИСЕРТАЦІЙ тощо;

- визначено перелік полів і підполів для заповнення і зроблено відповідні налаштування інтерфейсу електронного каталогу;

- визначено відповідальних за бази даних і прописано права доступу;

- розроблено нормативно-інструктивну й методичну документацію, зокрема «Положення про електронний каталог Державної науково-педагогічної бібліотеки України ім. В. О. Сухомлинського», інструкцію «Правила заповнення полів у базах даних «Дисертації» та «Автореферати дисертацій» електронного каталогу Державної науково-педагогічної бібліотеки України ім. В. О. Сухомлинського» та методичні рекомендації з координатного індексування документів і заповнення поля «Ключові слова»;

- визначено перелік формальних підзаголовків електронного каталогу;

- створено необхідні вбудовані словники, довідники тощо.

Станом на 1.01.2007 р. обсяг баз даних склав 6450 БЗ, з них:

- 1582 БЗ дисертацій;

- 1834 БЗ авторефератів дисертацій;

- 3034 БЗ книжок.

Робота проходила доволі успішно, однак інтеграційні процеси, що відбуваються у світі і впливають на форми міжбібліотечної взаємодії і характер відносин взаємодіючих суб'єктів, висвітлили розуміння того, що бібліотеки, виконуючи дедалі складніші завдання, не вправі існувати роздроблено й ізольовано одна від одної, тобто спонукали до корпоративної взаємодії. Оскільки багато освітянських бібліотек України на той час уже працювали або планували працювати з використанням САБ «ІРБІС», у Бібліотеці, як головному координаційному центрі мережі освітянських бібліотек МОН України і НАПН України, було ухвалено рішення про перекомутування ЕК в інше програмне забезпечення.

Із середини 2006 р. фахівці бібліотеки почали освоювати САБ «ІРБІС»: пройшли навчання, визначили і створили потрібні бази даних ЕК, розробляли нормативноінструктивну й методичну документацію для роботи з ЕК і почали наповнення БД. Спочатку було освоєно версію «ІРБІС32», а згодом - «ІРБІС64». Практично з цього ж часу здійснюється конвертування бібліографічних записів, створених за допомогою програмного забезпечення «MARC-SQL», у програмне забезпечення «IPБIC».

В основі успішного функціонування сучасної наукової бібліотеки лежить автоматизована система пошуку відомостей і надання доступу до віддалених баз даних через телекомунікаційні мережі. Але впровадження будь-якої інновації передбачає адаптування до складних бібліотечних технологій, напрацьовуваних роками, i, як наслідок, нові труднощі. Зокрема, найважливішим у переході на інше програмне забезпечення $\epsilon$ дотримання умови збереження вже накопичених відомостей 3 
можливістю її подальшого використання. Це й обумовило актуальність здійснюваної роботи.

Мета роботи з конвертування БЗ - створення єдиного електронного каталогу для відображення відомостей про всі види документів, які надходять до Бібліотеки, на різних носіях інформації із застосуванням технології конвертування бібліографічних записів з АІБС «MARC-SQL» до САБ «ІРБIC».

\section{2. РЕЗУЛЬТАТИ ДОСЛІДЖЕННЯ}

\section{1. Технологія роботи}

Конвертування (від лат. «converto») - це перетворення чого-небудь в іншу форму або в іншу координатну систему. Розробники САБ «ІРБІС64» заклали можливість конвертування Б3 за допомогою вбудованого багатофункціонального конвертора 3 формату USMARC у формат RUSMARC з наступним глобальним корегуванням.

Стандартна технологія конвертування БЗ передбачає подану нижче послідовність операцій.

1. Увійти в ЕК, створений у програмі «MARC-SQL».

2. У базі даних «КНИГИ» відібрати (помітити) бібліографічні записи, що потребують конвертування.

3. На панелі інструментів у спадаючому меню від кнопки «ДОКУМЕНТ» вибрати операцію «Позначені документи відібрати як підмножина».

4. На панелі інструментів у спадаючому меню кнопки «СЕРВIC» вибрати операцію «Експорт в MARC-формат» - Кодування (Unicode) UTF-8 скрипт - «Експорт документів разом з обліковими записами» - Зберегти.

5. У САБ ІРБІС відкрити базу даних, до якої імпортуватимуться БЗ (у нашому випадку базу даних Книги).

6. На панелі інструментів у меню «СЕРВІС» натиснути кнопку «ІМПОРТ», відкрити вікно «Імпорт даних у БД...», після чого вибрати такі функції: Формат вихідних даних - ISO; TBП переформатування - MMARCI (3 формату «MARC» (USMARC) з подальшим глобальним корегуванням, Кодування UTF-8 - виконати.

7. Після завершення операції «Конвертування» конвертовані записи редагують.

\section{2. Результати роботи}

Перша спроба конвертування відразу показала, що цей процес не простий i тривалий. Наприклад, після конвертування перших Б3 у вікні перегляду в бібліографічних записах не відображалися відомості про відповідальність, тобто колективів, співавторів, редакторів, перекладачів тощо у вікні перегляду не було. Як з'ясувалося, після конвертування обов'язково слід робити глобальне корегування записів. Для цього треба:

- відібрати (позначити) документи для корегування;

- на панелі інструментів активізувати кнопку «Корегування»;

- у спадаючому меню вибрати операцію «Глобальне»;

- на панелі вікна «Глобальне корегування БД» - Завдання на корегування відкрити папку «Відкрити», після чого у вікні «Вибір файлу завдання» вибрати операцію USPM - «Корегування БД після імпорту у форматі «MARC» (USMARC)» - Виконати - у відкритому вікні «Глобальне корегування БД...» натиснути кнопку 
«Повернення». За результатом цих дій у запису і вікні перегляду з'являються відомості про відповідальність.

Далі в процесі конвертування постали інші проблеми міжсистемного перенесення даних, а саме: бібліографічні записи переносяться частково або з помилками, а в деяких випадках зовсім не переносяться. Це зумовлено багатьма чинниками: в системах «IPБIC» $\mathrm{i}$ «MARC-SQL» існують різні набори полів для створення Б3, поля мають різні назви, їх наповнення трактують по-різному i, як наслідок, створюють записи також порізному. Попри це, у САБ «ІРБIC64» немає повної відповідності формату RUSMARC, хоча це й задекларовано, а конвертор представлено як повнофункціональний, що дає змогу вільно імпортувати записи у внутрішньо системний UNIMARC практично без помилок. На жаль, такого не відбулося. Неузгодження виникали й через те, що під час створення бібліографічних записів українською мовою використовується російськомовна версія «ІРБІС64».

Попри всі труднощі, роботу було почато з конвертування БЗ дисертацій, яких тоді в ЕК було майже 1600. Цей вибір був обумовлений тим, що, по-перше, ці документи найчастіше замовляють користувачі-науковці, оскільки дисертації містять актуальні, науково обгрунтовані теоретичні або експериментальні результати, особливо цінні наукові положення; по-друге, бібліографічно опрацьовувати ці документи простіше, ніж інші, оскільки для описування дисертацій використовують сталий набір обов'язкових і факультативних елементів: їх завжди описують під автором, немає співавторів, редакторів, перекладачів тощо, відсутні такі дані як «Видавництво», «Серія», «Різночитання назв» та багато іншого. Аналогічно описують й автореферати дисертацій. Конвертування БЗ авторефератів дисертацій (понад 1800) було здійснено відразу після закінчення конвертування БЗ дисертацій.

Після завершення конвертування дисертацій і авторефератів дисертацій почалося конвертування Б3 усіх інших документів - багатотомників, серіальних й продовжуваних видань, видань, що мають більше одного автора й інших осіб, відповідальних за створення документа, документів багатьох авторів без загальної назви тощо. недоліки.

У результаті конвертування документів різних типів було виявлено подані нижче

1. Зовсім не конвертуються:

- персональні предметні рубрики (особи, організації);

- індекси ББК;

- каталожні індекси;

- географічні рубрики;

- паралельні назви;

- форма, вид, жанр матеріалу (монографія, підручник і т. ін.);

- № запису в КСУ (Книга сумарного обліку);

- ціна примірника.

2. Предметні рубрики конвертуються частково, тобто конвертується лише предметний заголовок без підзаголовків (у тому числі географічного, хронологічного, формального).

3. Інформація 3 поля «Розширення ініціалів» («MARC-SQL») потрапляє в підполе «Різночитання прізвищ» поля 700: 1-ий автор - Заголовок опису («ІРБІС64»), звідки їі слід було обов'язково перенести у відповідне підполе; у протилежному разі «засмічується» словник «Автори».

4. Ключові слова в «MARC-SQL» були записані в одне поле, підряд, через кому або через крапку 3 комою; програма давала змогу здійснювати пошук окремо за кожним 3 них. В «ІРБІС64» це поле конвертується в такому ж вигляді, але пошук за 
окремим словом (словосполученням) здійснити неможливо, тож кожне ключове слово доводиться переносити в окремий рядок.

5. Якщо документ має більше трьох авторів і його описують під назвою, після конвертування відомості про авторів потрапляють в поле 702 «Редактори, укладачі, композитори» замість поля 701 «ншші індивідуальні автори». Задля отримання коректної БЗ ці дані з поля 702 треба переносити вручну в поле 701.

6. Автор-колектив (організація), який не є заголовком запису, попадає в поле 710 «Заголовок запису» замість поля 711 «Інші колективи, що не входять до заголовку запису»;

7. Інвентарний номер конвертується разом із позначкою місця зберігання видання (к - книгосховище, ф1 - філія); у програмі «MARC-SQL» такий запис був коректним, а в програмі «ІРБІС64» інвентарний номер і позначка місяця зберігання повинні заноситись в окремі підполя.

8. Не завжди конвертується «Зона серії» (поле 225) за винятком підполя «Відомості, що стосуються назви»; у програмі «MARC-SQL» ці дані записувалися в поле «Примітки», тому в «ІРБІС64» вони також потрапляють у поле «Примітки», і їх необхідно переносити у відповідне підполе поля «Зона серії».

У процесі конвертування виявилася ще така особливість: у «MARC-SQL» немає розбивки на робочі аркуші залежно від того, який документ описують, - усі БЗ створювалися за одним шаблоном (крім описування періодики), відмінності визначалися набором полів у відповідних БД.

На початку роботи в програмі «ІРБІС» було ухвалено рішення, що описи будьяких документів здійснюватимуться в робочому аркуші PAZK42 Опис книги «Під заголовком», «Під автором», «Під колективним автором» без виділення однотомних, багатотомних або продовжуваних видань. Під час конвертування БЗ окремих випусків продовжуваних видань або окремих томів багатотомників в «ІРБІС» ці відомості автоматично лягають на робочий аркуш SPEC42 «Опис специфікації тому». Після конвертування БЗ таких видань всі намагання зробити бібліографічний запис коректним і правильним на робочому аркуші PAZK42 не дали позитивного результату, тому після певних доопрацювань було вирішено залишити БЗ таких записів на робочому аркуші SPEC42 «Опис специфікації тому».

Зазначимо ще й таке: створювати електронний каталог співробітники бібліотеки розпочали у 2003 р. За цей час отримано багатий досвід зі створення БЗ, особливо стосовно таких доволі складних питань, як предметизація й індексування ключовими словами. Тому, доопрацьовуючи конвертовані записи, доводиться більш ретельно переглядати згадані складові запису, часто змінювати їх або доповнювати, - тобто відбувається повноцінне науково-методичне редагування БЗ.

\section{3. ВИСНОВКИ ТА ПЕРСПЕКТИВИ ПОДАЛЬШИХ ДОСЛІДЖЕНЬ}

Питання конвертування записів 3 АІБC «MARC-SQL» у CAБ «IPБIC», на нашу думку, надзвичайно складне, але нині вкрай потрібне. Незважаючи на значні трудовитрати (у рік це 85-100 годин), цю роботу слід продовжувати й завершити якнайшвидше, оскільки розпорошеність відомостей про фонд бібліотеки в різних електронних каталогах, один 3 яких недоступний користувачам, погіршує якість обслуговування.

Пояснити досить повільний темп роботи можна двома причинами. Перша. Недосконалість вбудованого конвертора спричинює значні затрати часу на редагування записів. Усі неконвертовані відомості доводиться копіювати в «MARC-SQL» і вручну вносити у відповідні поля програми «ІРБІС64». На жаль, іншого доступного конвертора бібліотека поки що немає. Комерційна фірма «МАТРІКС ПРЕС» пропонує конвертор 
«МУСіК», який, як зазначають розробники, дає змогу в режимі on-line конвертувати записи, створені в одній із систем: «IPБIC», «MARC-SQL» та УФД-Бібліотека - в будьяку з цих систем, перетворюючи формат і структуру, прийняті в одній системі, в записи для іншої системи [3]. Але якість цього продукту поки що невідома, та й коштує він недешево (200-500 грн на місяць).

Друга причина - відсутність будь-яких методичних рекомендацій щодо конвертування в супроводжувальній документації до САБ «ІРБІС», щоб дало змогу прискорити цей процес. Як уже зазначалось вище, публікацій, присвячених проблемам конвертування, нами виявлено також не було. Тож доводилось працювати, як кажуть, методом спроб і помилок.

3 огляду на розширення корпоративних зв’язків і залучення до них бібліотек, які працюють у різному програмному забезпеченні, щоб запобігти невиправданим трудовитратам, працівники книгозбірень мають пам'ятати:

- конвертування - це доволі складний процес, і займатися цією роботою мають фахівці, добре обізнані як і з програмним забезпеченнями «MARK-SQL, так і $з$ «ІРБІС»;

- конвертувати записи бажано невеликими партіями для зручності наступного редагування;

- через відсутність єдиного центру корпоративної каталогізації проблема обміну Б3 досі залишається невирішеною; тому бажано було б створити такий мультисистемний конвертор, який би задовольняв різноманітні потреби споживачів, які використовують різні програмні продукти, був доступним i зручним у користуванні. У цьому полягає найближча перспектива.

\title{
СПИСОК ВИКОРИСТАНИХ ДЖЕРЕЛ
}

1. Беззуб І. О. Кооперація як резерв розвитку діяльності бібліотек ВНЗ [Електронний ресурс] / Ірина Олександрівна Беззуб // Міжнародна наукова конференція «Адаптація завдань і функцій наукової бібліотеки до вимог розвитку цифрових інформаційних ресурсів». - Київ, 2013. - Режим доступу : http://conference.nbuv.gov.ua/report/view/id/82. - Назва з екрана. - Дата доступу 10.12.2014 p.

2. Волковой A. On-line инструменты для поддержки корпоративного взаимодействия библиотек по обмену библиографическими ресурсами [Електронний ресурс] / Алексей Волковой // Матрикс Пресс. - Режим доступа : http://matriks-pres.com.ua/index.php/statti-matriks/32-is-matriks/208-on-lineinstrumenty-dlya-podderzhki-korporativnogo-vzaimodejstviya. - Назва 3 екрана. - Дата доступу 10.12.14 г.

3. Коваленко С. Г. Бібліографічна Зведена база даних дисертацій - складова інтегрованого галузевого інформаційного ресурсу / Світлана Коваленко // Вісник книжкової палати. - 2014. - № $2(211)$. - C. $14-17$.

4. Пестрякова С. Н. Внедрение ИРБИС 64 в Научную библиотеку Якутського государственного университета им. М. К. Аммосова [Електронний ресурс] / С. Н. Пестрякова. - Режим доступу : http://libr.s-vfu.ru/konf2009/2_11.htm. - Назва з екрану. - Дата доступу 10.11.2014 г.

Матеріал надійшов до редакиії 03.03. 2015 p.

\section{КОНВЕРТИРОВАНИЕ БИБЛИОГРАФИЧЕСКИХ ЗАПИСЕЙ ИЗ АИБС «МАRС- SQL» В САБ «ИРБИС»: ПРОБЛЕМЫ И ИХ РЕШЕНИЕ}

\author{
Коваленко Светлана Георгиевна \\ научный сотрудник отдела научной обработки документов и организации каталогов \\ Государственная научно-педагогическая библиотека Украины имени В. А. Сухомлинского, \\ г. Киев, Украина \\ skovalenko@yandex.ua
}




\begin{abstract}
Аннотация. Основной целью деятельности библиотечных организаций является формирование единого информационного пространства на основе объединения и взаимоиспользования ресурсов, а также интеграция в региональное, национальное, европейское и мировое пространство. Однако на пути к кооперации возникают препятствия, среди которых - проблемы межсистемного взаимодействия, которые препятствуют свободному обмену библиографическими данными и вынуждают библиотеки при создании различного рода корпораций объединяться по принципу одинаковых автоматизированных библиотечно-информационных систем. Статья посвящена конвертированию библиографических записей из программы АИБC «MARC-SQL» в программу САБ «ИРБИС», проблемам, которые возникли в ходе этой работы и путям их решения.
\end{abstract}

Ключевые слова: конвертирование; конверторы; кооперация; автоматическая информационно-библиотечная система; АИБС; система автоматизации библиотек; САБ; «MARC-SQL»; «ИРБИС».

\title{
CONVERTING OF BIBLIOGRAPHIC RECORDS FROM «MARC-SQL» ILS INTO «IRBIS» LAS: PROBLEMS AND WAYS OUT
}

\author{
Svitlana H. Kovalenko \\ researcher of the Department of Scientific Processing Documents and Organizing Catalogues \\ V. Sukhomlynskyi State Scientific and Pedagogical Library of Ukraine, Kyiv, Ukraine \\ skovalenko@yandex.ua
}

\begin{abstract}
The main purpose of libraries activities is to form integrated information space on the basis of pooling and using of resources and integration into regional, national, European and world space. However, on the way of cooperation there are some obstacles among them are problems of intersystem cooperation, which prevent from free bibliographic information exchange and make libraries to merge with each other according to the principle of identical integrated library system when establishing different corporations. The article deals with converting of bibliographic records from «MARC-SQL ILS program into «IRBIS» LAS program, with the problems arisen in the cause of this work and the ways of solving such problems.
\end{abstract}

Keywords: converting; converters; cooperation; Integrated Library System; ILS; Library Automation System; LAS; «MARC-SQL»; «IRBIS».

\section{REFERENCES (TRANSLATED AND TRANSLITERATED)}

1. Bezzub I. O. Cooperation as a reserve of the development activities of the University libraries [online] / Iryna Oleksandrivna Bezzub // Mizhnarodna naukova konferentsiia "Adaptation tasks and functions of the scientific library of the requirements for the development of digital information resources». - Kyjiv, 2013. - Available from : http://conference.nbuv.gov.ua/report/view/id/82. - Name from screen. - Date of access 10.12.2014 r. ( in Ukrainian).

2. Volkovoy A. On-line instrument to support corporate interaction libraries for the exchange of bibliographic resources [online] / Aleksey Volkovoy // Matriks Press. - Available from : http://matrikspres.com.ua/index.php/statti-matriks/32-is-matriks/208-on-line-instrumenty-dlya-podderzhkikorporativnogo-vzaimodejstviya. - Name from screen. - Date of access 10.12.2014 r. (in Russian).

3. Kovalenko S. H. Summary bibliographic database of dissertations - component integrated industry information resource / Svitlana Kovalenko // Visnyk knyzhkovoi palaty. - 2014. - № 2 (211). - S. 14-17 ( in Ukrainian).

4. Pestryakova S. N. The introduction of IRBIS 64 in the Scientific library Jakutskogo state University named after M. K. he was appointed a position [online] / S. N. Pestryakova. - Available from : http://libr.s-vfu.ru/konf2009/2_11.htm. - Name from screen. - Date of access 10.12.2014 r. (in Russian). 